Герасимов Г. Г., к.т.н., доцент, Герасімов Є. Г., к.т.н. доцент, Іванов С. Ю., інженер (Національний університет водного господарства та природокористування, м. Рівне)

\title{
РОЗРАХУНОК КОНУСНОГО ФІЛЬТРА ДЛЯ ПОПЕРЕДНЬОГО ОЧИЩЕННЯ ВОДИ
}

В статті розглянуто конструкцію конусного фільтра для попереднього механічного очищення води, який розташовується всередині напірного трубопроводу насосної станції. Виконаний розрахунок процесів внутрішнього і зовнішнього промивання сітчастого полотна фільтра і забезпечення допустимої швидкості обертання промивної флейти В результаті розрахунків визначені основні геометричні і гідравлічні параметри пристрою.

Ключові слова: конусний сітчастий фільтр, промивна флейта, потокоутворювач гвинтового потоку, брудовідвід, забезпечення обертання флейти.

В системі кулькового очищення (СКО) конденсатора, не зважаючи на наявність грубих решіток і більш тонкого очищення води в обертових решітках на вході в циркуляційні насоси, існує необхідність, для надійної роботи кулькового очищення і підтримання мінімального гідравлічного опору, застосування періодичного промивання сіток конічного фільтра. Промивання повинно виконуватися на ходу без перемикання і без зупинки СКО [1].

В теперішній час отримав найбільше розповсюдження в паротурбінних установках потужністю 100, 200, 250, і 300 МВт конусний фільтр осьового типу. Вершина конуса напрямлена на зустріч потоку, з кутом розкриття $(16 \ldots 18)^{\circ}$, рис. 1.

Фільтруюча поверхня конуса утворена перфорованим листом 3 нержавіючої сталі товщиною 2...3 мм з отворами діаметром 8 мм. Сумарна площа отворів в 2,5...3 рази перевищує площу поперечного перерізу трубопроводу. Очищення фільтруючої поверхні від сміття виконується струменями води під напором з сопел діаметром 6-8 мм, які встановлені перпендикулярно внутрішньої поверхні фільтруючого конуса. Вода до промивних сопел з напором 30-35 м підводиться від обертового промивного пристрою, який змонтовано на порожнистому валу. Змите сміття потоком води виноситься через скидний 
брудовідвід в зливний циркуляційний водовід.

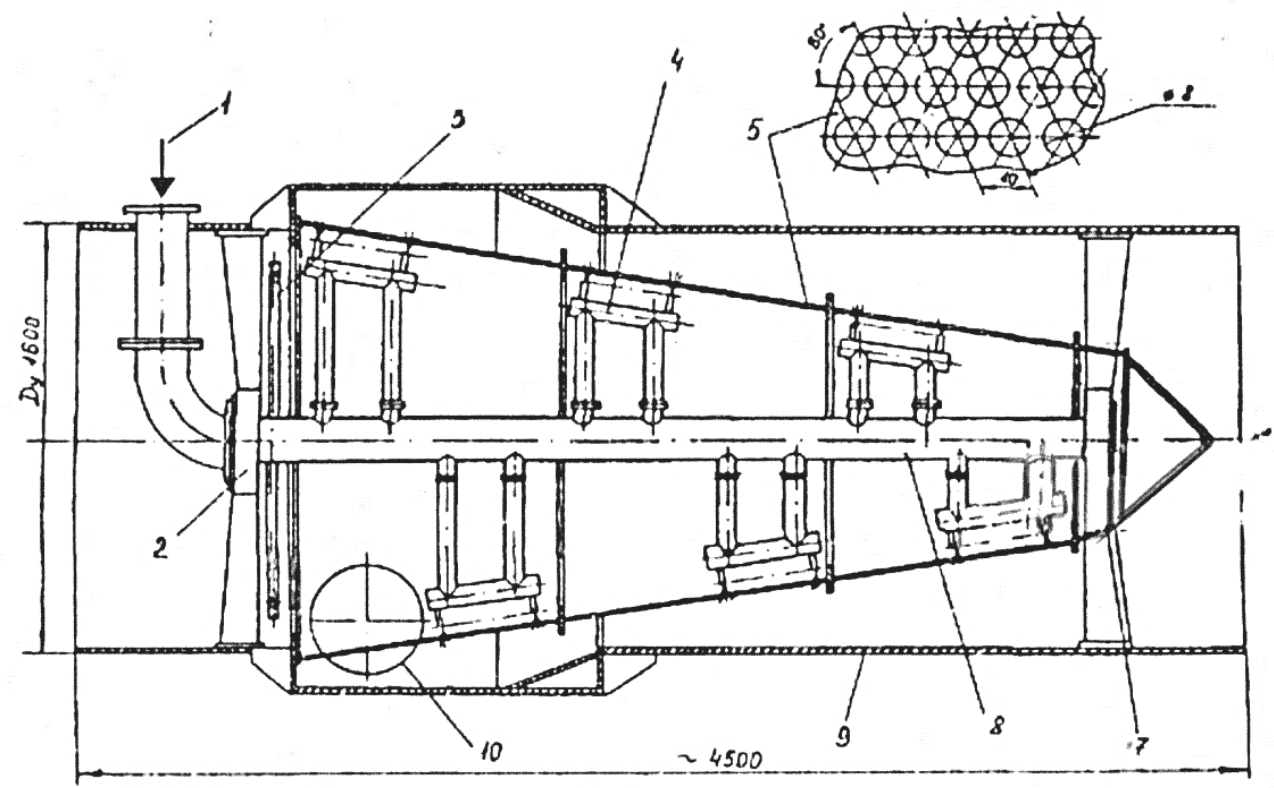

Рис. 1. Конусний фільтр попереднього очищення води:

1 - підведення води до промивного пристрою; 2 - підшипник; 3 - гідропривод промивного пристрою (сегнерово колесо); 4 - колектор з соплами; 5 - фільтруюча сітка з нержавіючої сталі; 6 - підведення циркуляційної

води; 7 - підшипник; 8 - обертовий промивний пристрій (флейта); 9 - напірний водовод циркуляційної води; 10 - скидання забрудненої води

Витрата води на промивний пристрій біля $200 \mathrm{~m}^{3} /$ год. Витрата забрудненої води не повинна перевищувати (3...5)\% витрати води циркуляційного трубопроводу. Період промивки фільтра 3...5 хв. Гідравлічний привод промивного пристрою діє за принципом сегнерового колеса, за рахунок реактивної дії струменів води, яка витікає під тиском зі спеціальних сопел, що тангенційно встановлені на колекторі приводу промивного пристрою. Оптимальна швидкість обертання промивного пристрою $10 \ldots 16$ об/хв. Вода на промивний пристрій 3 напором не менше $30 . .35$ м подається спеціальним насосом СД450/56 с подачею 450 м³/год і напором 56 м. Досвід експлуатації більш ніж 40 осьових фільтрів показав, що дана конструкція ФПО працездатна і рекомендується для впровадження. Важливою перевагою такого фільтра $є$ можливість розміщення його всередині водоводу.

Вказані значення характерних величин фільтра приведені як орієнтовні. Природно, що для кожної конкретної установки швидкість обертання промивного пристрою, витрата промивної води, три- 
валість промивання і інші показники встановлюються в процесі проведення налагоджувальних робіт.

Тепер розроблена модифікація ФПО конусного типу, але скороченої довжини [1]. Якщо повсемісно впроваджена конструкція ФПО має довжину $4 \ldots 4,5$ м, то довжина розробленої конструкція становить 2,5 м. Скорочення довжини виконано за рахунок збільшення кута конусу сітки до $40 . .50^{\circ}$ і зменшення відношення площі отворів до площі поперечного перерізу водопроводу до 1,4; оскільки, як встановлено дослідом експлуатації, основною робочою зоною фільтра попередньої конструкції $є$ вихідна частина сітки на довжині однієї третини, рис. 2.

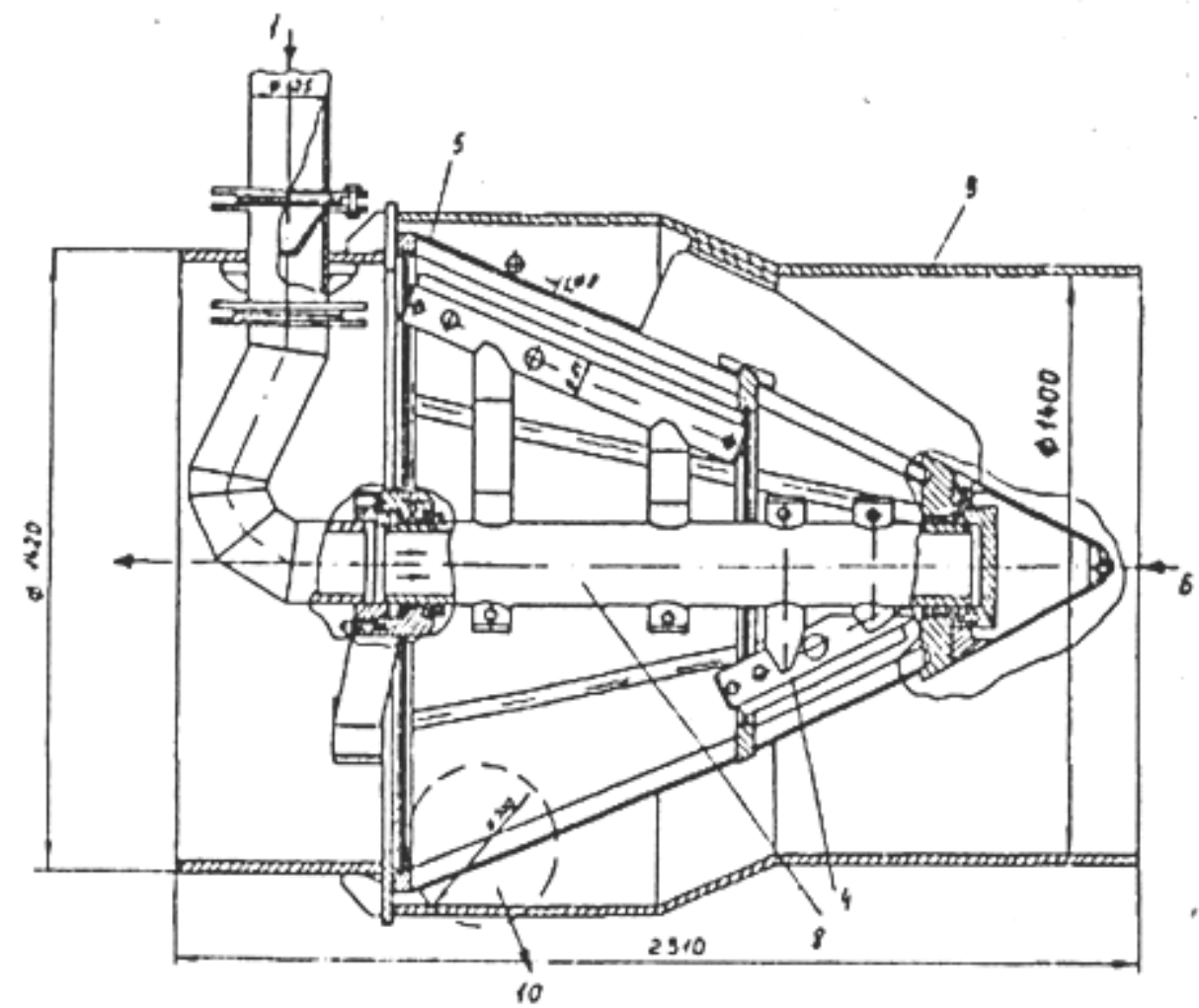

Рис. 2. Конусний малогабаритний фільтр попереднього очищення: позначення аналогічні рис. 1

Проходять дослідну експлуатацію ФПО конусного типу з фільтруючим полотном з плетеної дротяної сітки, діаметр нержавіючого дроту, з якого виготовлена сітка - 1 мм, чарунка сітки $5 \times 5$ мм. Застосування дротяної сітки для ФПО зменшує гідравлічний опір фільтра, а також знижує витрату металу. 
Оптимальна частота обертання $10 \ldots 16$ об/хв. Більша частота обертання призводить до прискореного зносу підшипників і менш сприятлива для ефективного виносу забруднень в скидний водовід.

Контроль за частотою обертання виконується за індикатором обертання (IO), яким $€$ манометр, що показує стрибок тиску при проходженні соплом промивного пристрою при його обертанні торця імпульсної трубки, яка іде до манометра. Частота обертання визначається за числом імпульсів за тиском (стрибків тиску), на які реагує стрілка манометра.

Для правильної роботи 10 необхідно виконати наступні умови:

- повинна бути забезпечена співвісність торця імпульсної трубки, яка іде до манометра, і вибраного для контролю одного з сопел промивного пристрою;

- відстань між торцями імпульсної трубки і сопла повинно бути 10-15 мм;

- клас точності манометра для чіткого сприйняття імпульсу повинен бути не нижче 1,0; а межі вимірювання 0-4 кГс/ $\mathrm{cm}^{2}$;

- відстань від виводу імпульсу до манометра повинна бути мінімальною.

При проектуванні ФПО с гідроприводом в ньому передбачається завідомо збільшена кількість сопел. Для зменшення частоти обертання повинно бути заглушено якась кількість сопел, що встановлюється дослідним шляхом. Отриманий вітчизняний досвід показує, що встановлення перед конденсатором фільтра для очищення води від завислого сміття різного характеру опиняється економічно доцільним для конденсаторів парових турбін, навіть коли вони не оснащені СКО.

Фільтр попереднього очищення (ФПО), який встановлено на Хмельницькій AEC, призначений для захисту тракту циркуляції (конденсаторних трубок, трубних дощок) від механічних крупнодисперсних забруднень, рис. 3. Це найбільш складний елемент, який повинен забезпечити промивку своїх фільтруючих елементів на працюючому енергоблоці, не впливаючи на роботу турбогенератора [2].

Основним елементом фільтра $€$ конусна сітка, яка складається 3 окремих секцій, з'єднаних між собою. Матеріалом сітки фільтра слугує листова нержавіюча сталь 3 отворами діаметром 8 мм. Сумарна площа отворів фільтруючої сітки в два рази перевищує площу поперечного переріз напірного водовода. 


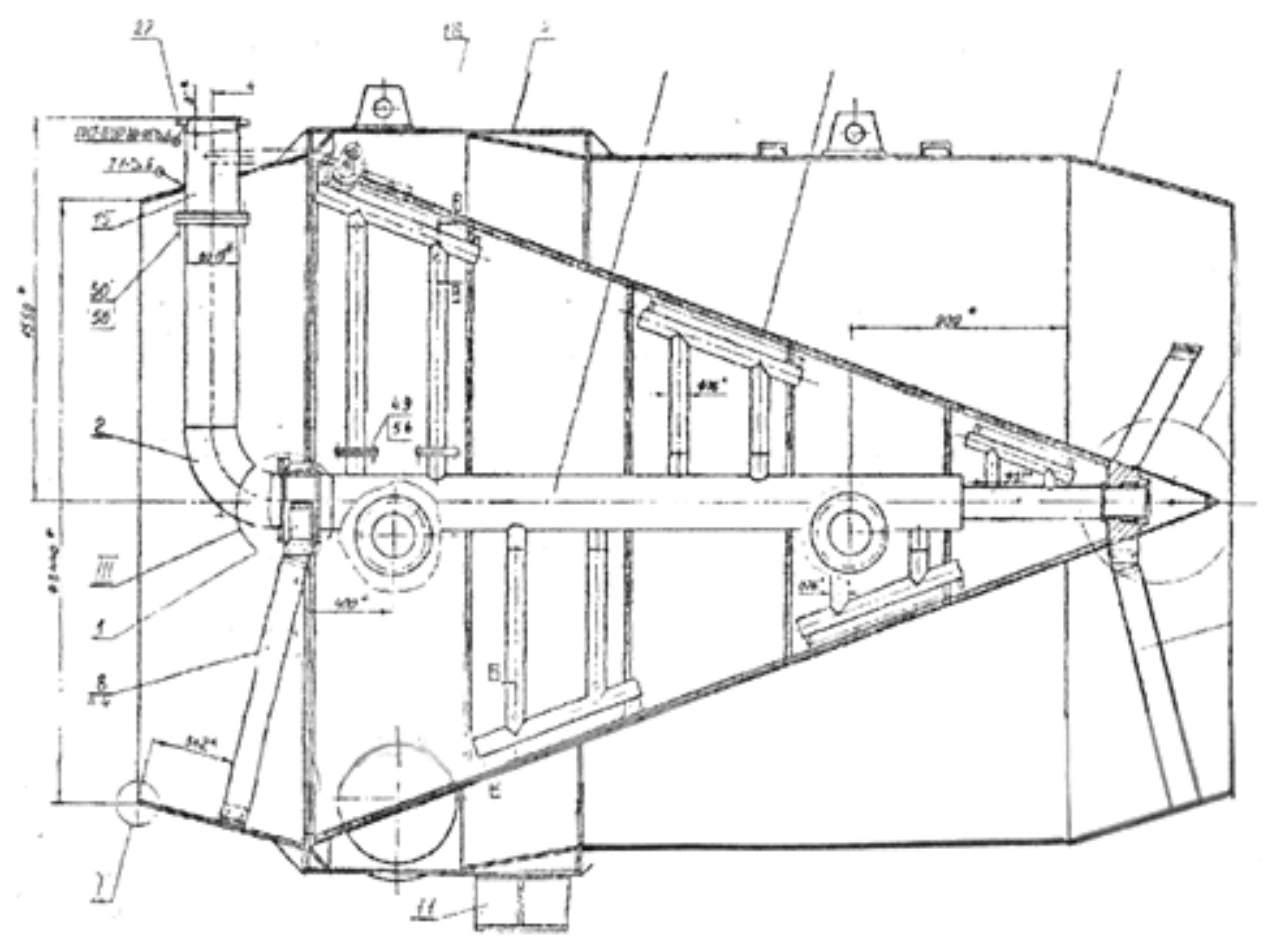

Рис. 3. Поздовжній переріз фільтра попереднього очищення води

Всередині перфорованого конусу фільтра з боку чистої сторони розташований промивний апарат, який складається з обертового колектора діаметром $273 \times 6$ мм з встановленими на ньому патрубками 3 соплами. Обертання промивного пристрою виконується за рахунок реактивної дії струмин води, яка витікає з чотирьох спеціально встановлених сопел.

В вихідній частині ФПО має скидний трубопровід діаметром 530х8 мм для відводу забруднень при відмивання фільтруючих полотен.

Загальний гідравлічний опір ФПО при номінальній витраті води і чистих фільтруючих полотнах повинен бути не більше 700 мм вод. ст., а засміченого, при якому повинно починатися відмивання фільтра, - не більше 1000 мм вод. ст. Максимально допустимий опір ФПО при забрудненні або збільшенні витрати води не повинен перевищувати 1500 мм вод. ст. При підвищенні гідравлічного опору ФПО до 1000 мм вод. ст. подається світлозвуковий сигнал на БЩУ.

Вода, що поступає з сопел промивного апарата з тиском не менше 6 кГс/см², відділяє сміття, яке затрималося на зовнішній стороні сітки, і виносить його у скидний трубопровід. Витрата циркуляційної води, що скидається при промиванні ФПО не повинен пере- 
вищувати 10\% від витрати води, яка поступає на конденсатор, що практично не впливає на роботу турбоустановки. Тривалість промивної операції 10-15 хвилин.

Насос промивних пристроїв ФПО Д-800-57 призначений для подачі промивочної води на патрубок з соплами для відмивання фільтруючого полотна, а також на сопла, за допомогою яких відбувається обертання змивного апарата. Продуктивність насоса $800 \mathrm{~m}^{3} /$ год при напорі 57 м вод. ст.

Для вимірювання гідравлічного опору ФПО на напірному цирководоводі перед і за фільтром на відстані 0,5 м врізані імпульсні трубки діаметром 14х2 мм, встановлений датчик Сапфир 22ДД-2430. Покази дифманометра виводяться на МЩ, границя показів $0,15 \kappa Г c / \mathrm{cm}^{2}$. Швидкість обертання промивного пристрою контролюється електроконтактним манометром типу ЕКМ-14, який встановлюється на спеціальному патрубку фільтра і вловлює тиск змивної води в момент співпадіння осей сопла обертового промивного пристрою $\mathrm{i}$ патрубка манометра. Сигнали від ЕКМ у вигляді електричних імпульсів подається на МЩ до сигнальних лампочок. Границя показів $2,5 \kappa \Gamma \mathrm{c} / \mathrm{cm}^{2}$.

Конденсатори приєднані до циліндра низького тиску попарно $\mathrm{i}$ з'єднані між собою послідовно по охолоджуючій воді, рис. 4.

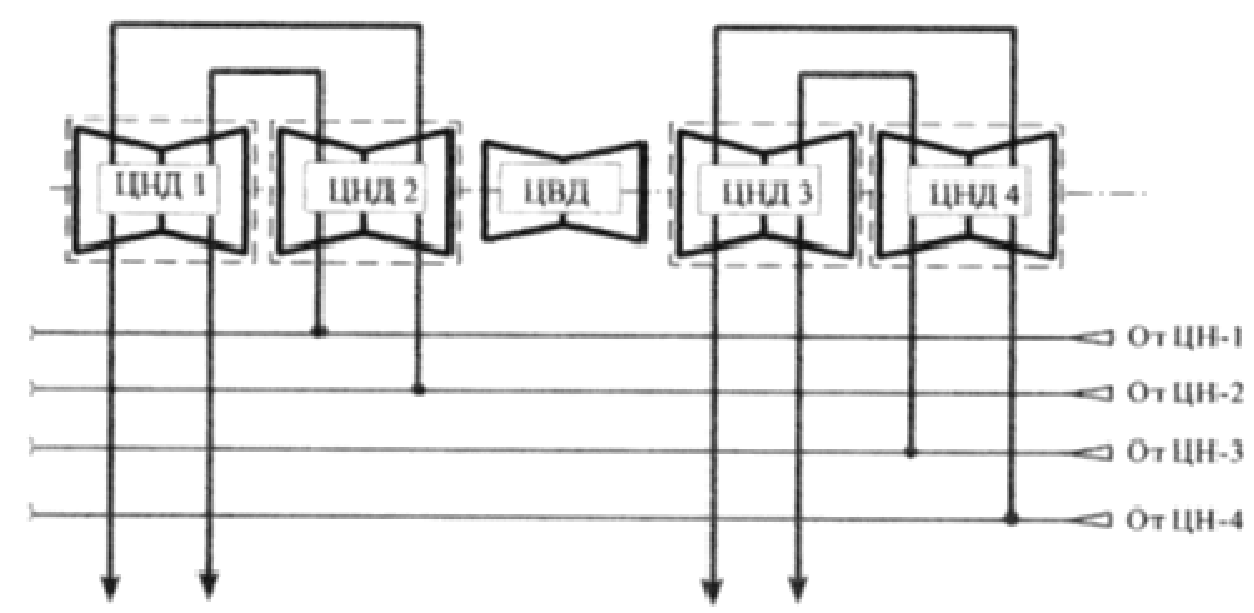

Рис. 4. Схема підведення циркуляційної води до конденсаторів

Циркуляційна вода від діагональних насосів марки 170 ДПВ$12 / 22$ окремими для кожного насосу водоводом діаметром $D_{y}=2440$ мм підводиться до конденсаторів, проходить паралельними потоками всередині трубок в поворотні камери, після чого також двома паралельними потоками проходить другу пару конденсаторів і 
далі через чотири колодязя відповідно для кожного скидного трубопроводу $D_{y}=2440$ мм потрапляє в закритий залізобетонний відвідний канал перерізом 6,0×4,0 м, звідки через дюкер потрапляє на полігональну сифонну споруду з регульованою висотою переливу порогу і далі в відвідний канал і водосховище [2]. Конденсатори мають різний тиск конденсації, який відповідає температурі води, що послідовно проходить через них. Геометричний об'єм обох збірників конденсату складає приблизно 9,8 м³. Нормальна робота конденсаційної установки забезпечується неперервним відведенням теплоти конденсації пари, за рахунок проходження охолоджуючої води через конденсатори, неперервним відведенням газів і повітря з вакуумної системи турбіни і відведенням конденсату 3 конденсатозбірника. Повітря 3 конденсаторів видаляється за допомогою чотирьох водоструминних ежекторів EB-7-1000. Два водоструминних ежектора EB-1-230 призначені для відведення повітря при пусках циркуляційних насосів.

Система циркуляційного водопостачання машзала Хмельницької AEC (Блок № 1) призначена для забезпечення відведення тепла відпрацьованої пари в турбіні і його конденсацію в конденсаторах основної турбіни і приводної турбіни (ПТН), а також для охолодження робочого середовища в підсистемах циркуляційного водопостачання турбінного відділення [2]. Система не виконує функції безпеки, вона відноситься до забезпечуючих систем.

Очищена вода після сіток потрапляє у всмоктувальну частину циркуляційних насосів, марки 170 ДПВ-12/22 ЕГ-УЗ. Насоси призначені для подачі прісної води в систему циркуляційного водопостачання турбінного відділення.

Циркуляційна вода від чотирьох працюючих насосів 170 ДПВ 12/22 УЗ поступає у чотири роздільних цирководовода Ду $=2400$ мм. 3 приміщення БНС під рівнем поверхні землі цирководоводи Ду = 2400 мм проходять вдовж турбінного відділення між блоками з боку ряду А.

На шляху протікання циркуляційна вода проходить камеру попереднього очищування циркуляційної води (КПО), рис. 5 і рис. 6. В КПО циркуляційна вода проходить очищення на механічних фільтрах - конусних сітчастих фільтрах.

На рис. 7 представлений поздовжній переріз конусного фільтра [4] (Патент на корисну модель. Україна. № 100840 B01D 35/02). Завданням корисної моделі $€$ підвищення надійності очищення води від завислих і волокнистих частинок бруду шляхом організації сприятливої структури потоку зовні конусного екрана. 


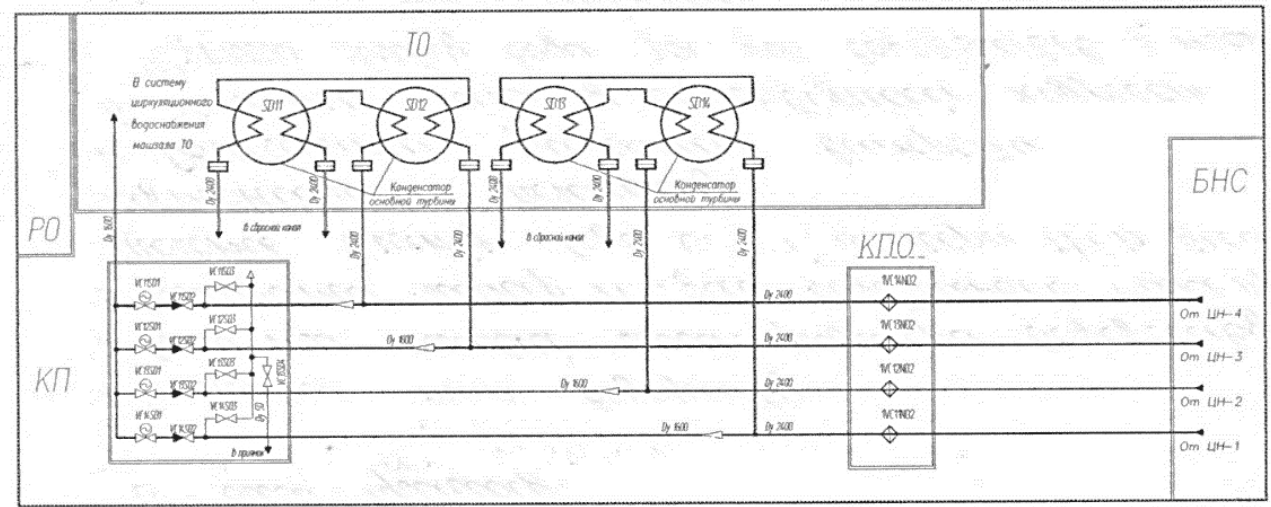

Рис. 5. Маршрут потоку основної циркуляційної води і розташування КПО [2]

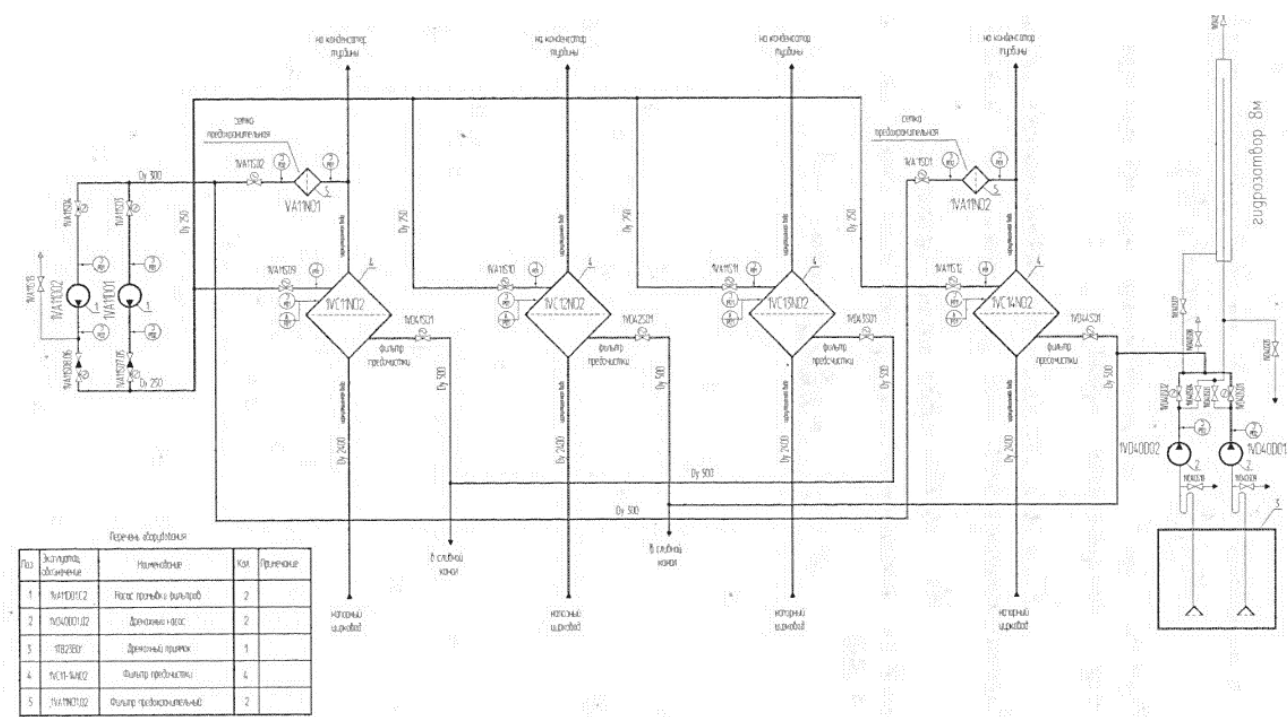

Рис. 6. Технологічна схема КПО (Блок № 1) [2]

Поставлене завдання досягається тим, що конусний фільтр для очищення води вміщує конусний водопроникнений екран, розташований в трубопроводі і напрямлений назустріч потоку води; змивну флейту з промивними отворами, розміщену в підшипниках з можливістю обертання навколо осі конуса; брудовідвід; напірну трубу для подачі води у флейту і в голові конуса розташований потокоутворювач з соплами, які напрямлені під гострим кутом до осі конуса. 


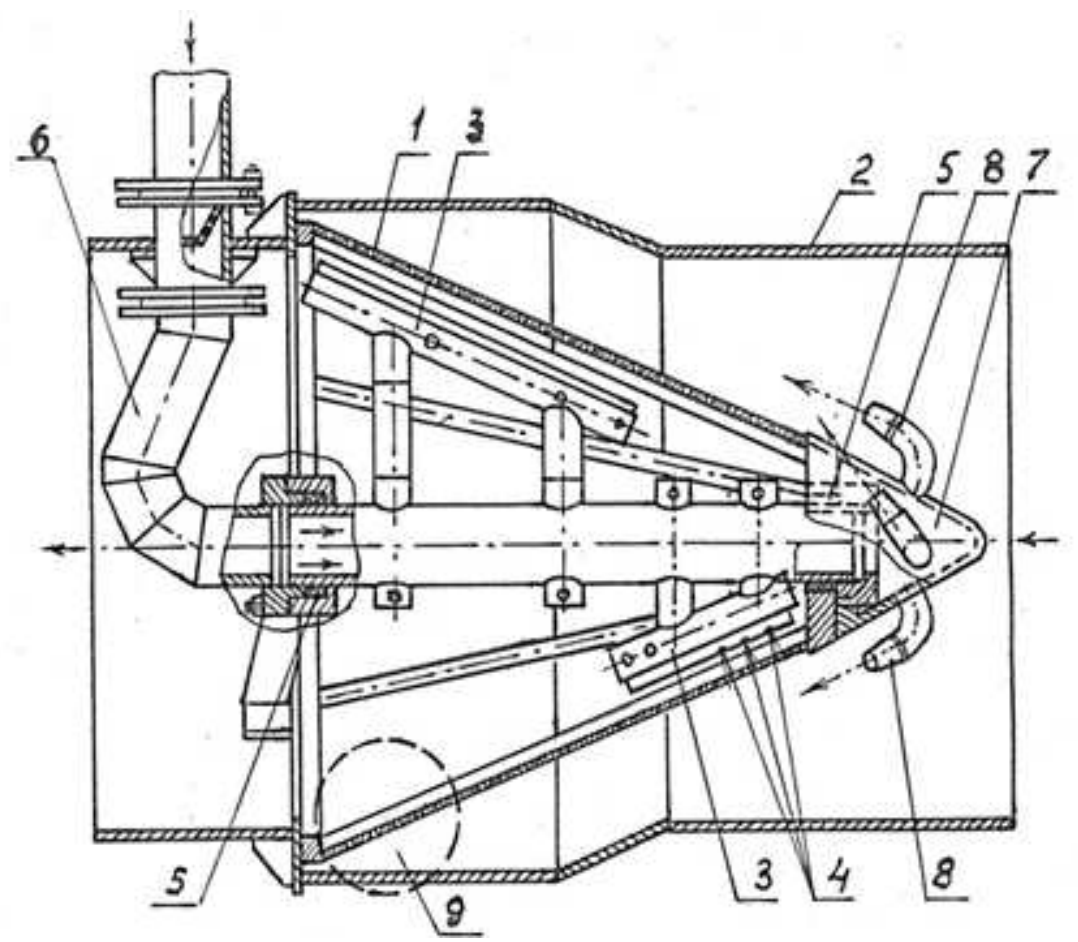

Рис. 7. Конусний фільтр для очищення води

1 - конусна сітка, 2 - трубопровід, 3 - промивна флейта, 4 - отвори в промивній флейті, 5 - підшипник, 6 - промивна труба, 7 - вихідний конус, 8 - потокоутворювач - сопла з насадками, які розташовані під кутом до осі конуса, 9 - брудовідвід

Для цього конусну замкнену камеру при вершині конуса сполучають з промивною трубою і оснащують соплами, які створюють гідравлічні струмені, що напрямлені під гострим кутом до осі конуса, наприклад під кутом $45^{\circ}$. Кількість сопел може бути від 4 до 8 і більше в залежності від діаметра трубопроводу.

На рис. 7 показаний поздовжній переріз конусного фільтра для очищення води. Конусний фільтр для очищення води вміщує водопроникнений конусний екран 1, розташований в трубопроводі 2 і напрямлений вершиною назустріч потоку води; змивну флейту 3 з промивними отворами 4, розміщену в підшипниках 5 з можливістю обертання навколо осі конуса; напірну трубу 6, яка входить зовні в трубопровід і подає воду у флейту 3; брудовідвід 7; потокоутворювач 8 з соплами 9, які напрямлені під гострим кутом до осі конусу.

Конусний фільтр для очищення води працює наступним чином. 3 початком роботи насосної установки потік води в трубопроводі 2 набігає на водопроникнену поверхню конусного екрана 1. Коли вми- 
кається промивний насос і з'являється тиск в напірному трубопроводі 6, починає обертатися флейта 3 за рахунок дії спеціальних тангенціальних струменів 3 флейти 3, починається промивання конусного екрана 1 радіальними струменями 3 отворів 4 флейти 3 і струмені 3 сопел 9 потокоутворювача 8 створюють гвинтову структуру потоку зовні конусного екрана 1 і за рахунок відцентрових сил частинки бруду, що відхилені струменями з отворів 4, відкидаються в периферійну зону трубопроводу 2 і за гвинтовою лінією потрапляють у брудовідвід 7.

При наявності потокоутворювача з соплами, які нахилені до осі конуса піл гострим кутом і створюють гвинтову структуру в потоці, який надходить на конусну водопроникнену поверхню, надійність промивання отворів конусного екрана і попереднього очищення води покращується. Це призводить до більш надійної роботи пристроїв, що споживають очищену воду, і забезпечує зменшення простоювання в ремонтах названих пристроїв.

Розрахунок конусного фільтра для попереднього очищення циркуляційної води охолодження конденсатора турбіни виконується для насоса 170 ДПВ-12/22 ЕГ-УЗ, $n=290$ об/хв, 3 подачею $Q_{H}=12 \mathrm{~m}^{3} / \mathrm{c}$ і напором $H_{p}=22 \mathrm{~m}$. Діаметр напірного трубопроводу $d_{H}=$ $2440 \mathrm{MM}$.

\section{Проектування конусної сітки}

Приймаємо кількість насосів, що подають воду через одну конусну сітку $Z_{\kappa c}=1$. Розрахункова витрата - конусної сітки $Q_{p в}=Q_{H} Z_{\kappa c}=$ $12 \mathrm{~m}^{3} / \mathrm{c}$.

Згідно рекомендацій [1] приймаємо фільтруюче полотно з плетеної дротової сітки. Діаметр нержавіючого дроту, з якого виготовлена сітка, $-d_{д p}=1$ мм; чарунка сітки $5 \times 5$ мм. Застосування дротової сітки для ФПО зменшує гідравлічний опір фільтра, а також знижує витрату металу.

При розташуванні конусної сітки в середині напірного трубопроводу, приймаємо діаметр більшої основи конуса $D_{б о}=1,1 d_{H}$ $=1,1 * 2,44=2,70 \mathrm{M}$, а діаметр меншої основи $D_{\text {мо }}=0,15 d_{H}=0,15 * 2,44=$ 0,40 м. Приймаємо кут конуса сітки $2 \alpha=45^{\circ}$, тоді $\alpha=22,5^{\circ}$. Висота зрізаного конуса

$h_{\kappa}=0,5\left(D_{б о}-d_{\text {мо }}\right) \operatorname{ctg} \alpha=0,5(2,7-0,4) \operatorname{ctg} 22,5^{\circ}=2,8 \mathrm{M}$.

Коефіцієнт живого перерізу сітки за формулою

$$
f c=[b /(b+d)]^{2}=[5 /(5+1)]^{2}=0,694 .
$$

Згідно рекомендацій [1] приймаємо витрату брудовідводу $Q_{б p}=0,05 Q_{p в}=0,05 \cdot 12=0,6 \mathrm{~m}^{3} / \mathrm{c}$. Приймаємо діаметр брудовідводу 
$d_{б p}=0,5$ м, тоді швидкість в брудовідводі буде $v_{б p}=\frac{4 Q}{\pi d_{\sigma p}^{2}}=\frac{4 \cdot 0,6}{3,14 \cdot 0,5^{2}}=$ $3,06 \mathrm{~m} / \mathrm{c}$.

Площа конусної сітки, як площа бокової поверхні зрізаного конуса, без урахування засмічення і затінення

$$
S_{1}=\pi\left(R^{2}-r^{2}\right) / \sin \alpha,
$$

де $R=D_{6 о} / 2=2,7 / 2=1,35 \mathrm{M}$ - радіус більшої основи конуса; $r=D_{\text {мо }} / 2=0,4 / 2=0,2$ м - радіус меншої основи конуса;

$S_{1}=3,14\left(1,35^{2}-0,2^{2}\right) / \sin 22,5^{\circ}=14,63 \mathrm{~m}^{2}$.

Довжина твірної сітчастого конуса $L=(R-r) / \sin \alpha=(1,35-$ $0,2) / 0,382=3,01 \mathrm{~m}$.

Площа живого перерізу конусної сітки

$$
S_{c}=\frac{f_{c} S_{1}}{K_{3} K_{\kappa}},
$$

де $K_{3}=1,18$ - експлуатаційний коефіцієнт засмічення сітки; $K_{k}=1,05$ коефіцієнт, що враховує затінення сітки елементами конструкції.

$$
S_{c}=\frac{0,694 \cdot 14,63}{1,18 \cdot 1,05}=8,194 \mathrm{M}^{2} .
$$

Швидкість входження води в конусну сітку фільтра

$$
v_{B x}=\frac{Q_{p 8}}{S_{c}}=\frac{12}{8,194}=1,46 \mathrm{~m} / \mathrm{c} .
$$

Проектування промивної флейти

Приймаємо насос для промивних пристроїв - флейти, марки Д 800-57, який призначений для подачі води до сопел, які відмивають фільтруюче полотно конуса; на сопла, за допомогою яких відбувається обертання флейти і для подачі води в потокоутворювач, за допомогою якого створюється зовнішній гвинтовий рух води навколо конусної сітки. Подача насоса $Q_{n н}=800 \mathrm{~m}^{3} /$ год $=0,222 \mathrm{~m}^{3} /$ с при напорі $H_{n р}=57$ м. Таким чином, сумарна витрата на промивні пристрої становить $Q_{\text {пр }}=0,222 \mathrm{~m}^{3} /$ с; в тому числі на промивну флейту $Q_{\phi}=0,01 Q_{p в}$ $=0,01 \cdot 12=0,12 \mathrm{M}^{3} / \mathrm{c} ;$ на пристрій обертання флейти $Q_{\text {по }}=0,0015 Q_{p в}$ $=0,0015 \cdot 12=0,018 \mathrm{~m}^{3} / \mathrm{c}$; на потокоутворювач $Q_{\text {пу }}=0,007 Q_{p в}=$ $=0,007 \cdot 12=0,084 \mathrm{M}^{3} / \mathrm{c}$.

Оптимальна швидкість обертання флейти $10 . . .16$ об/хв. Приймаємо швидкість обертання флейти $\pi=10$ об/хв.

Визначаємо необхідну кількість плечей флейти при $\xi=1,2 Z_{\phi}=$ $\xi Q_{p 8} /\left(K_{3} n S_{c}\right)=1,2 \cdot 12 /(1,18 \cdot 10 \cdot 8,194)=0,149$ шт. Приймаємо $Z_{\phi}=2$ шт. 
Розмір вічка сітки $d_{p}=b_{4}=5 \mathrm{mм}$. Діаметр дроту сітки $d=1 \mathrm{mм.}$ Знаходимо діаметр отворів флейти $d_{o}=2, d_{p}=2 \cdot 5=10$ мм $=0,01$ м. Відстань від флейти до сітки згідно з формулою $\Delta l=5, d_{p}=5.5=25$ мм. Приймаємо $\Delta l=25$ мм. Крок отворів за формулою $l=2 \Delta l=2 \cdot 25=50$ мм.

Приймаємо коефіцієнт витрати отворів $\mu=0,6$. Кількість отворів промивної флейти $n_{\text {от }}=0,5 Z_{\phi} L /(l \cos \alpha)=0,5 \cdot 2 \cdot 3,01 /\left(0,05 \cdot \cos 22,5^{\circ}\right)=$ $=65$ шт. Приймаємо $n_{\text {от }}=65$ шт.

Необхідно визначити втрати напору у всмоктувальному і напірному трубопроводі прийнятого відцентрового насоса Д 800-57 з подачею $Q_{n р}=0,222 \mathrm{~m}^{3} /$ с при напорі $H_{n р}=57$ м. Приймаємо діаметри всмоктувального і напірного трубопроводів відповідно $D_{B}=0,5 \mathrm{M} \mathrm{i}$ $D_{H}=0,4$ м. Середні швидкості води в трубопроводах

$$
\begin{aligned}
& v_{B}=\frac{Q_{n p}}{\pi d_{B}^{2} / 4}=\frac{0,222}{3,14 \cdot 0,5^{2} / 4}=1,13 \mathrm{M} / \mathrm{c} . \\
& v_{B}=\frac{Q_{n \mu}}{\pi d_{H}^{2} / 4}=\frac{0,222}{3,14 \cdot 0,4^{2} / 4}=1,76 \mathrm{M} / \mathrm{c} .
\end{aligned}
$$

Довжина всмоктувального трубопроводу $L_{B}=100$ м; а напірного $L_{H}=300 \mathrm{M}$.

Втрати напору знаходимо за формулою:

$$
h_{w}=\lambda \frac{L}{D} \cdot \frac{v^{2}}{2 g} .
$$

де $\lambda$ - коефіцієнт втрат напору за довжиною трубопроводу, який для сталевих труб знаходиться за формулою

$$
\lambda=\frac{0,021}{D^{0,3}} .
$$

Згідно з наведеними формулами з урахуванням місцевих опорів знаходимо:

$$
\begin{aligned}
& \lambda_{B}=\frac{0,021}{D_{B}^{0,3}}=\frac{0,021}{0,5^{0,3}}=0,0258 ; \quad \lambda_{H}=\frac{0,021}{D_{H}^{0,3}}=\frac{0,021}{0,4^{0,3}}=0,02766 ; \\
& h_{w s}=1,1 \lambda_{B} \frac{L_{B}}{D_{B}} \cdot \frac{v_{B}^{2}}{2 g}=1,1 \cdot 0,0258 \frac{100}{0,5} \cdot \frac{1,13^{2}}{2 \cdot 9,81}=0,37 \mathrm{M} ; \\
& h_{w H}=1,1 \lambda_{H} \frac{L_{H}}{D_{H}} \cdot \frac{v_{H}^{2}}{2 g}=1,1 \cdot 0,2766 \cdot \frac{300}{0,4} \cdot \frac{1,76^{2}}{2 \cdot 9,81}=3,58 \mathrm{M} .
\end{aligned}
$$

Сумарні втрати напору $h_{w}=h_{w B}+h_{w H}=0,37+3,58=3,95 \approx 4 \mathrm{M}$.

Напір, який витрачається на створенні швидкості в соплах флейти, промивних соплах і соплах потокоутворювача, дорівнює

$$
H_{\phi}=H_{n p}-h_{w}=57-4=53 \mathrm{M} \text {. }
$$


Необхідна площа отвору сопла флейти

$$
f_{\text {om }}=\frac{Q_{\phi}}{\mu n_{\text {OT }} \sqrt{2 g H_{\phi}}}=\frac{0,12}{0,6 \cdot 65 \sqrt{2 \cdot 981 \cdot 53}}=0,000097 \mathrm{~m}^{2} .
$$

Тоді діаметр отвору сопла $d_{\text {om }}=\sqrt{\frac{4 f_{O T}}{\pi}}=\sqrt{\frac{4 \cdot 0,000097}{3,14}}=0,0124 \mathrm{M}$, тобто практично таке ж значення, яке було прийнято раніше, $d_{0}=0,01$ м. Приймаємо остаточно $d_{o т}=0,01 \mathrm{M}$. Тоді площа отвору сопла $f_{O T}=\pi d_{O T}{ }^{2} / 4=3,14 \cdot 0,01^{2 \cdot} / 4=0,0000785 \mathrm{~m}^{2}$.

Швидкість води в отворі сопла флейти

$$
v_{o}=\frac{Q}{f_{\text {OT }} n_{\text {OT }}}=\frac{0,12}{0,0000785 \cdot 65}=23,52 \mathrm{M} / \mathrm{c} \text {. }
$$

Знаходимо діаметр промивної напірної труби флейти, виходячи 3 середньої швидкості $v_{\text {сер }}=3 \mathrm{~m} / \mathrm{c}$.

$$
d_{n p}=\sqrt{4 Q_{n p} /\left(\pi v_{n p}\right)}=\sqrt{4 \cdot 0,222 /(3,14 \cdot 3)}=0,307 \mathrm{M} .
$$

Приймаємо промивний трубопровід стандартного діаметра $d_{n р}=0,3 \mathrm{M}$.

Згідно рис. 7 кількість радіальних труб флейти дорівнює чотирьом, тому витрата однієї радіальної труби $Q_{p т}=Q_{\phi} / 4=0,12 / 4=$ $=0,03 \mathrm{~m}^{3} / \mathrm{c}$. При швидкостях води в вертикальних і розподільчих трубах $v_{B}=5 \mathrm{~m} / \mathrm{c}$ їх діаметр

$$
d_{p т}=\sqrt{4 Q_{p m} /\left(\pi v_{p m}\right)}=\sqrt{4 \cdot 0,03 /(3,14 \cdot 5)}=0,087 \text { м. Приймаємо }
$$
$d_{p \mathrm{~T}}=0,075 \mathrm{M}$.

Позначення розмірів елементів промивної флейти конусного фільтра наведені на рис. 8.

3 геометричних міркувань і розрахунків прийняти наступні розміри елементів промивного пристрою - флейти фільтру:

$R_{1}=1,08 \mathrm{M} ; R_{2}=0,18 \mathrm{M} ; R_{3}=0,504 \mathrm{M} ; R_{4}=0,81 \mathrm{~m} ; R_{5}=0,36 \mathrm{M} ;$

$R_{6}=0,25 \mathrm{M} ; R_{7}=0,36 \mathrm{M} ; R_{8}=0,20 \mathrm{M} ; R_{9}=0,48 \mathrm{M} ;$

$l_{1}=0,38 \mathrm{M} ; l_{2}=0,36 \mathrm{M} ; l_{3}=0,21 \mathrm{M} ; l_{4}=0,054 \mathrm{M}$;

$L_{1}=1,57 \mathrm{M} ; L_{2}=0,80 \mathrm{M}$.

Проектування потокоутворювача

Витрата води на потокоутворювач $Q_{\text {пу }}=0,084 \mathrm{~m}^{3} / \mathrm{c}$ при напорі $H_{\phi}=53 \mathrm{M}$.

Приймаємо кількість сопел потокоутворювача $n_{\text {пу }}=6$ шт і коефіцієнт витрати сопла $\mu=0,6$. Визначаємо площу поперечного перерізу сопла потокоутворювача 


$$
f_{n y}=\frac{Q_{n y}}{\mu n_{n y} \sqrt{2 g H_{\phi}}}=\frac{0,084}{0,6 \cdot 6 \sqrt{2 \cdot 9,81 \cdot 53}}=0,00072 \mathrm{~m}^{2} .
$$

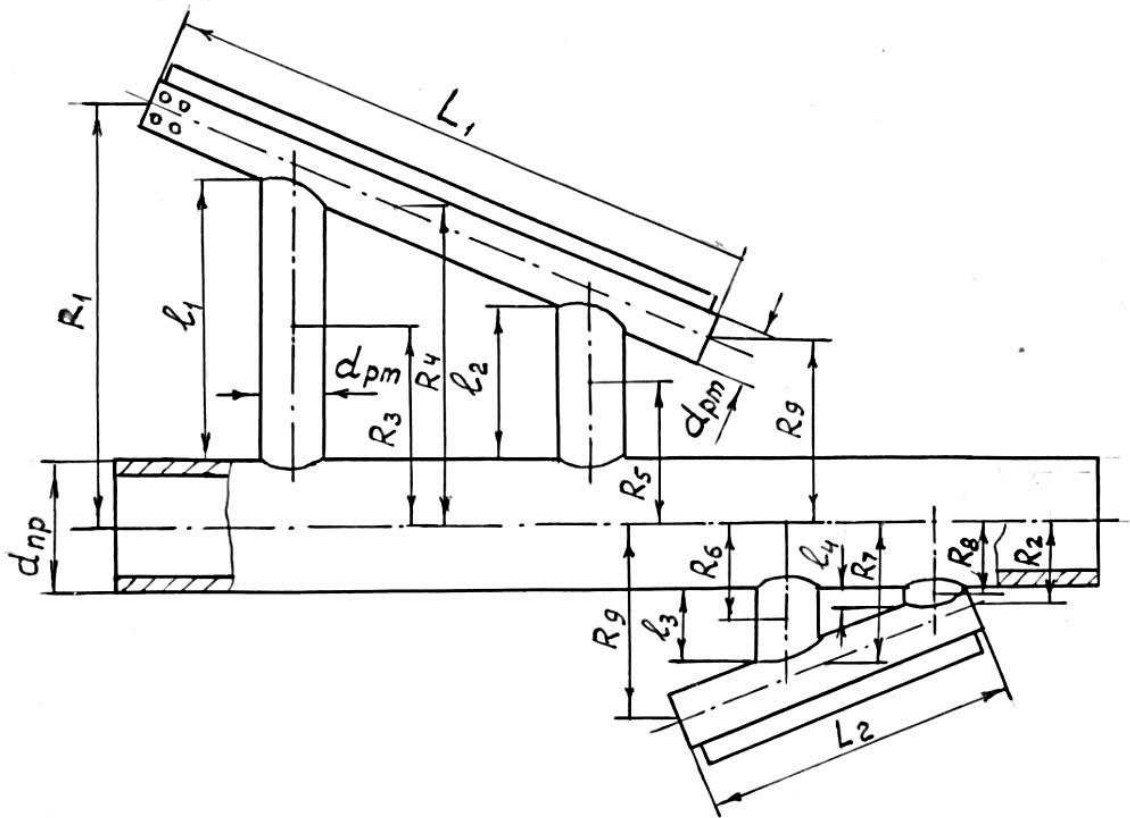

Рис. 8. Схема промивної флейти конусного фільтра

Діаметр сопла потокоутворювача

$$
d_{n y}=\sqrt{\frac{4 f_{n y}}{\pi}}=\sqrt{\frac{4 \cdot 0,00072}{3,14}}=0,03 \mathrm{M} .
$$

Швидкість води на виході з сопла

$$
v_{n y}=\frac{Q_{n y}}{n_{n y} f_{n y}}=\frac{0,084}{6 \cdot 0,00072}=19,44 \mathrm{M} / \mathrm{c} .
$$

Середня швидкість в промивному струмені з потокоутворювача в кінці конусної сітки повинна бути на менше $0,2 \mathrm{~m} / \mathrm{c}$ [5, С. 189], тобто повинна виконуватися умова $v_{c \kappa} \geq 0,2 \mathrm{~m} / \mathrm{c}$.

Середня швидкість струменя в перерізі, який знаходиться на відстані $L$ від перерізу насадка, при витіканні в воду у стані спокою (за М. В. Коноваловим) [6, С. 93]

$$
v_{c \kappa}=m v_{n y} d_{n y} /\left[\left(1+m d_{n y} / L\right) L\right],
$$

де $m$ - постійна, $m=2,9$.

$$
v_{c \kappa}=2,9 \cdot 20,05 \cdot 0,03 /[(1+2,9 \cdot 0,03 / 3,01) 3,01]=0,562 \mathrm{M} / \mathrm{c} \text {. }
$$

Умова виконується.

Розрахунок пристрою обертання флейти 
За теоретичними розробками Назарова Н. Т. при рівномірному обертанні флейти має місце динамічна рівновага [7, С. 13]

$$
M_{\kappa p}=M_{o п},
$$

де $M_{к р}$ і $M_{\text {оп }}$ - відповідно моменти крутячих сил і сил опору обертанню. В свою чергу

$$
M_{\text {оп }}=M_{\text {мех }}+M_{\text {гідр, }}
$$

де $M_{\text {мех }}$ - момент механічного тертя у підшипниках, $M_{\text {гідр }}-$ момент сил гідравлічного опору. Для даної конструкції рекомендується приймати постійним $M_{\text {мех }}=0,3 \mathrm{H} \cdot \mathrm{M}$, а момент сил гідравлічного опору визначають за формулою

$$
M_{\text {гідр }}=0,5 \rho C_{x} \omega^{\top} \Sigma F_{i} R_{i}^{1+m},
$$

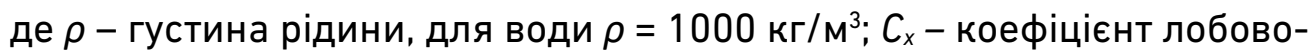
го опору, $\omega$ - кутова частота обертання флейти, $m$ - показник степеню при швидкості у формулі для гідравлічних втрат; $F_{i}, R_{i}-$ площа $\left(\mathrm{M}^{2}\right)$ міделевого перерізу елемента флейти і радіус (м) його обертання.

За експериментальними дослідженнями Петрика А. Д. [7, С. 25] $m=2 ; C_{x}=1,6$. Швидкість переміщення сопел промивної флейти (переносна швидкість) при прийнятій частоті обертання $\Pi=10$ об/хв дорівнює $u_{\phi}=\pi D n / 60=3,14 \cdot 1,08 \cdot 10 / 60=0,565 \mathrm{~m} / \mathrm{c}$. При розташуванні осі сопел на діаметрі $D_{\phi}=D_{6}-2 b-d_{\phi}$, кутова частота обертання флейти буде

$$
\omega=2 u_{\phi} / D_{\phi} .
$$

Для флейти радіус розподільників $R_{i}=D_{\phi} / 2 \mathrm{i}$ висота флейти $h_{\phi}=h_{\sigma}-b$; тоді

$$
\begin{array}{r}
\Sigma F_{i} R_{i}{ }^{1+m}=Z_{o}\left[d_{\phi} h_{\phi}\left(D_{\phi} / 2\right)^{3}+2 d_{\phi}\left(D_{\phi} / 2\right)\left(D_{\phi} / 4\right)^{3}\right]= \\
=Z_{o} d_{\phi} D_{\phi}{ }^{3}\left(h_{\phi} / 8+D_{\phi} / 64\right) .
\end{array}
$$

Таким чином, момент сил гідравлічного опору стає можливим визначити за формулою (4.2).

Крутячий момент знаходять за залежністю

$$
M_{\kappa p}=\alpha_{o} \rho Q_{п p} R_{\phi}\left(\left(Q_{\Pi p} / f\right) \sin \delta-\omega R_{\phi}\right),
$$

де $\alpha_{o}$ - коефіцієнт Бусінеска для струменю; $Q_{\text {пр }}$ витрата води на флейті при промивці, м³/с; $R_{\phi}$ - радіус плеча флейти, $R_{\phi}=D_{\phi} / 2, \mathrm{~m} ; f-$ сумарна площа перерізу отворів на флейті, $f=f_{\text {по ппо } ; ~} \delta$ - кут відхилення промивних струменів від радіального напряму. За експериментальними даними Петрика А. Д. $\alpha_{o}=1,2$; [7, С. 25]. Враховуючі наведені залежності і чисельні значення дослідних величин, з рівняння (4) визначають $\sin \delta$ і знаходять значення кута $\delta$.

Самоконтроль. Повинна виконуватися умова $\delta \leq 90^{\circ}$.

Визначаємо сумарний добуток міделевих перерізів елементів флейти на радіуси їх обертання в кубі за формулою аналогічною 
(6.94) згідно рис. 8

$\sum F_{i} R_{i}{ }^{3}=d_{p \tau} l_{1} R_{3}{ }^{3}+d_{p T} L_{1} R_{4}{ }^{3}+d_{p \tau} l_{2} R_{5}{ }^{3}+d_{p \tau} l_{3} R_{6}{ }^{3}+d_{p T} L_{2} R_{7}{ }^{3}+d_{p \tau} l_{4} R_{8}{ }^{3}=$

$=d_{p T}\left(l_{1} R_{3}{ }^{3}+L_{1} R_{4}{ }^{3}+l_{2} R_{5}{ }^{3}+l_{3} R_{6}{ }^{3}+L_{2} R_{7}{ }^{3}+l_{4} R_{8}{ }^{3}\right)$

$\Sigma F_{i} R_{i}{ }^{3}=0,075\left(0,38 \cdot 0,504^{3}+1,96 \cdot 0,81^{3}+0,36 \cdot 0,36^{3}+0,21 \cdot 0,25^{3}+1,02 \cdot 0,36^{3}+0\right.$, $\left.05 \cdot 0,2^{3}\right)=0,0869 \mathrm{M}^{5}$.

Кутова частота обертання за формулою (5)

$\omega=2 u_{\phi} / D_{\phi}=u_{\phi} / R_{1}=0,565 / 1,08=0,5231 / \mathrm{c}$.

Момент сил гідравлічного опору визначають за формулою (4)

$M_{\text {гідp }}=0,5 \rho C_{x} \omega^{\top} \Sigma F_{i} R_{i}{ }^{1+m}=0,5 \cdot 1000 \cdot 1,6 \cdot 0,523^{2} \cdot 0,0869=19,02 \mathrm{H}^{\cdot} \mathrm{M}$.

Момент механічних втрат у підшипниках флейти $M_{\text {мех }}=0,3 \mathrm{H} \cdot \mathrm{M}$.

Тоді момент сил опору обертанню за формулою (3)

$$
M_{\text {оп }}=M_{\text {мех }}+M_{\text {гідр }}=0,3+19,02=19,32 \mathrm{H} \cdot \mathrm{M} \text {. }
$$

Витрата води на пристрій обертання флейти $Q_{\text {по }}=0,018 \mathrm{~m}^{3} / \mathrm{c}$ при напорі $H_{\phi}=53 \mathrm{M}$. Приймаємо кількість сопел пристрою обертання флейти $n_{\text {по }}=4$ шт і коефіцієнт витрати сопла $\mu=0,6$. Визначаємо площу поперечного перерізу сопла пристрою обертання флейти

$$
f_{\text {по }}=\frac{Q_{n o}}{\mu n_{n o} \sqrt{2 g H_{\phi}}}=\frac{0,018}{0,6 \cdot 4 \sqrt{2 \cdot 9,81 \cdot 53}}=0,00023 \mathrm{~m}^{2} .
$$

Діаметр сопла пристрою обертання флейти

$$
d_{n o}=\sqrt{\frac{4 f_{n o}}{\pi}}=\sqrt{\frac{4 \cdot 0,00023}{3,14}}=0,0171 \mathrm{~m} .
$$

Швидкість води на виході з сопла

$$
v_{n o}=\frac{Q_{n o}}{n_{n o} f_{n o}}=\frac{0,06}{4 \cdot 0,00023}=19,56 \mathrm{M} / \mathrm{c} .
$$

Знаходимо кут відхилення струменів $\delta$ з формули (7) при $\alpha_{o}=1,2$;

$f=f_{\text {по }} \Pi_{\text {по }}=0,00023 \cdot 4=0,00092 \mathrm{~m}^{2} ; R_{\phi}=R_{1}=1,08 \mathrm{M} ; Q_{\text {по }}=0,018 \mathrm{~m}^{3} / \mathrm{c} ;$ $\rho=1000 \mathrm{\kappa r} / \mathrm{M} 3 ; \omega=0,523 \mathrm{c}-1$;

$$
M_{\text {кр }}=\alpha_{\circ} \rho Q_{\text {по }} R_{\phi}\left(\left(Q_{\text {по }} / f\right) \sin \delta-\omega R_{\phi}\right)=
$$

$=1,2 \cdot 1000 \cdot 0,018 \cdot 1,08[(0,018 / 0,00092) \sin \delta-0,523 \cdot 1,08]=12,96(20,45 \sin \delta$ $-0,565)$.

Виходячи з рівняння $M_{к р}=M_{\text {оп, тобто }}$

$19,32=12,96(20,45 \sin \delta-0,565)$, або $1,506=20,45 \sin \delta-0,565$. Звідси $\sin \delta=0,1013$ і $\delta=5,81^{\circ}$. Умова $\delta \leq 90^{\circ}$ виконується.

Розрахунок параметрів очищення сіток конуса

При очищенні сітки конуса системою струменів, які виходять 3 отворів сопел, дальність відкидання частинок Назаров Н. Т. рекомендує визначати за формулою 


$$
\check{S}=1,15 K_{c} K_{\Delta} K_{\Pi} \frac{\alpha A}{\omega R_{c}},
$$

де $\check{S}$ - середня статистична дальність відкидання часток від сітки, м; $K_{c}$ - коефіцієнт, який враховує вплив густості сітки; $K_{\Delta}$ - коефіцієнт, який враховує вплив відстані від флейти до сітки; $K_{\Pi}-$ коефіцієнт повноти епюри швидкостей; $\alpha$ - половина кута розтікання струменю, який виходить з промивного отвору (Г. Н. Абрамович рекомендує приймати $\alpha=0,216) ; \omega$ - кутова частота обертання флейти, $1 /$; $R_{c}-$ середній радіус флейти, $M, R_{c}=D_{\phi} / 2 ; A$ - параметр зануреного промивного струменю. Для осьосиметричних струменів параметр $A$ визначають із співвідношення

$$
V_{\text {стр }}=A / x_{0},
$$

де $x_{0}$ - довжина початкової ділянки осьосиметричного струменю $\left(x_{o}=5,0 d_{o}\right)$. За даними експериментальних досліджень Петрика А. Д. отримані такі емпіричні залежності

$$
\begin{gathered}
K_{c}=(4 / 3) c \\
K_{\Delta}=1-3,1 b \\
K_{\Pi}=1,05 \exp \left(\frac{0,55}{0,55-D_{\phi} /\left(6 t_{\kappa}\right)}\right),
\end{gathered}
$$

де $b$ - відстань від флейти до сітки; $D_{\phi}=$ середній діаметр флейти; $t_{\kappa}=$ крок отворів; C - коефіцієнт живого перерізу сітки, який знаходять за співвідношенням

$$
C=\frac{b_{u}^{2}}{\left(b_{u}+d\right)^{2}},
$$

де $b_{4}$ - розмір чарунки сітки, $d$ - діаметр дроту сітки.

Самоконтроль. Дальність відкидання частинок від сітки повинна бути більша ніж десята частина діаметра флейти, тобто $\check{S} \geq D_{\phi} / 10$.

Виконуємо розрахунки за приведеними залежностями при значеннях раніш визначених величин: $b=\Delta l=0,025 \mathrm{M} ; b_{4}=0,005 \mathrm{M}$; $d=0,001 \mathrm{M}$;

$$
\begin{aligned}
R_{\phi c}= & \left(R_{1}+R_{2}\right) / 2=(1,08+0,18) / 2=0,63 \mathrm{M} ; D_{\phi c}=2 \cdot R_{\phi c}=2 \cdot 0,63=1,26 \mathrm{M} . \\
t_{\kappa} & =l=0,05 \mathrm{M} ; d_{o}=d_{o T}=0,01 \mathrm{M} ; v_{c T p}=v_{o}=23,52 \mathrm{M} / \mathrm{c} ; \omega=0,5231 / \mathrm{c} ; \\
R_{c}= & R_{\phi c}=0,63 \mathrm{M} ; \alpha=0,216 . \\
C & =\frac{b_{u}^{2}}{\left(b_{u}+d\right)^{2}}=\frac{0,005^{2}}{(0,005+0,001)^{2}}=0,694 . \\
K_{c} & =(4 / 3) C=(4 / 3) \cdot 0,694=0,925 ; \\
K_{\Delta} & =1-3,1 b=1-3,1 \cdot 0,025=0,922
\end{aligned}
$$




$$
\begin{aligned}
& K_{\Pi}=1,05 \exp \left(\frac{0,55}{0,55-D_{\phi} /\left(6 t_{\kappa}\right)}\right)=1,05 \cdot \exp \left(\frac{0,55}{0,55-\frac{1,26}{6 \cdot 0,05}}\right)=0,45 \\
& x_{o}=5 d_{0}=5 \cdot 0,01=0,05 \mathrm{M} \text {; } \\
& A=v_{\text {стр }} \cdot x_{o}=23,52 \cdot 0,05=1,175 \text {. } \\
& \check{S}=1,15 K_{c} K_{\Delta} K_{\Pi} \frac{\alpha A}{\omega R_{c}}=1,15 \cdot 0,925 \cdot 0,922 \cdot 0,45\left(\frac{0,216 \cdot 1,175}{0,523 \cdot 0,63}\right)=0,368 \mathrm{M} \text {. }
\end{aligned}
$$

Таким чином, $\check{S}=0,368 \mathrm{M} \geq D_{\phi} / 10=1,26 / 10=0,126 \mathrm{M}$, тобто умова виконується.

До переваг конусних фільтрів слід віднести те, що на роботу засобу витрачується не більше 1...5\% води від витрати трубопроводу. Ефективна частота обертання промивного пристрою клапана складає від 4 до 15 обертів за хвилину для різних концентрацій забруднень води механічними частками. Повні гідравлічні втрати на конструкції складають від 0,2 до 0,4 м для різних режимів експлуатації, що в декілька разів менше аналогічних гідравлічних втрат на традиційних конструкціях водоочисних засобів, зокрема, водоочисних касетах.

Враховуючи вищезазначене, а також те, що при використанні конусних фільтрів відпадає необхідність ручного очищення фільтрів (що забирає в середньому до $10 . . .15 \%$ робочого часу), можна говорити про економічну доцільність використання конусної конструкції. До переваг конусних фільтрів необхідно віднести також їх невелику матеріалоємність, можливість модульного виготовлення для розміщення на насосних станціях, різної продуктивності. В теперішній час накопичено достатньо великий досвід конструювання і проектування пристроїв механічного очищення води різних типів, проте досвіду їх ефективної експлуатації явно недостатньо.

1. Методические указания по наладке и эксплуатации систем шариковой очистки конденсаторов паровых турбин. РД 34.30.403-93. М. : Служба передового опыта ОРГРЭС, 1994. 32 с. 2. Система циркуляционного водоснабжения машзала. Учебно-тренировочный центр ОП «Хмельницкая АЭС». 176 с. 3. Герасимов Г. Г. Проектування автоматизованих насосних станцій підкачки : навч. посібник. Рівне : НУВГП, 2007. 552 с. 4. Конусний фільтр для очищення води : пат. на корисну модель Україна № 100840, B01D 35/02. Опубл. 10.08.2015; Бюл. № 15. 4 с. 5. Малеванчик Б. С., Никоноров И. В. Рыбопропускные и рыбозащитные сооружения. М. : Легкая и пищевая пром-сть, 1984. 250 с. 6. Степанов П. М., Овчаренко И. Х., Скобельцин Ю. А. 
Справочник по гидравлике для мелиораторов. М. : Колос, 1984. 207 с. 7. Петрик А. Д. Гидравлические исследования сетчатых барабанов, ограждающих вход во всасывающие линии насосных станций : автореф. дис. ... канд. техн. наук. Укр. ин-т инж. водн. х-ва. Ровно, 1975. 23 с.

\section{REFERENCES:}

1. Metodicheskie ukazaniia po naladke i ekspluatatsii sistem sharikovoi ochystki kondensatorov parovykh turbin. RD 34.30.403-93. M. : Sluzhba peredovoho opyta ORHRЭS, 1994. 32 s. 2. Sistema tsirkuliatsionnoho vodosnabzheniia mashzala. Uchebno-trenirovochnyi tsentr OP «Khmelnitskaia AES». 176 s. 3. Herasymov H. H. Proektuvannia avtomatyzovanykh nasosnykh stantsii pidkachky : navch. posibnyk. Rivne : NUVHP, 2007. 552 s. 4. Konusnyi filtr dlia ochyshchennia vody : pat. na korysnu model Ukraina № 100840, B01D 35/02. Opubl. 10.08.2015; Biul. № 15. 4 s. 5. Malevanchik B. S., Nikonorov I. V. Rybopropusknye i rybozashchitnye sooruzheniia. M. : Lehkaia i pishchevaia prom-st, 1984. 250 s. 6. Stepanov P. M., Ovcharenko I. Kh., Skobeltsin Yu. A. Spravochnik po hidravlike dlia melioratorov. M. : Kolos, 1984. $207 \mathrm{~s}$. 7. Petrik A. D. Hidravlicheskie issledovaniia setchatykh barabanov, ohrazhdaiushchikh vkhod vo vsasyvaiushchie linii nasosnykh stantsii : avtoref. dis. ... kand. tekhn. nauk. Ukr. yn-t ynzh. vodn. kh-va. Rovno, 1975. 23 s.

Herasymov H. H., Candidate of Engineering (Ph.D.), Associate Professor, Gerasimov le. H., Candidate of Engineering (Ph.D.), Associate Professor, Ivanov S. Yu., Engineer (National University of Water and Environmental Engineering, Rivne)

\section{CALCULATION OF CONE FILTER FOR PRELIMINARY WATER CLEANING}

The article deals with the design of a conical filter for preliminary mechanical purification of water, which is located inside the pressure pipeline of a pumping station of steam turbine units. Filters for circulating pumps must ensure reliable ball cleaning and maintain minimum hydraulic resistance, and periodically flush the tapered filter nets. Flushing should be performed on the go without switching and without stopping.

The characteristics of cone filters are given.

The calculation of the processes of internal and external flushing of the mesh filter and ensuring the permissible speed of rotation of the flushing flute was performed. As a result of the calculations, the basic geometrical and hydraulic parameters of the device were determined. 
The advantages of cone filters include the fact that no more than 1 ... $\mathbf{5 \%}$ of water is consumed from the pipeline for flushing. The effective rotational speed of the valve flushing device is 4 to 15 revolutions per minute for different concentrations of water contamination by mechanical particles. Total hydraulic losses on the structure range from 0.2 to $0.4 \mathrm{~m}$ for different operating modes, which is several times less than the similar hydraulic losses on traditional designs of water treatment facilities, in particular, water treatment cartridges. Given the above, and the fact that the use of cone filters eliminates the need for manual cleaning of filters (which takes an average of 10 ... $15 \%$ of working time), we can speak about the economic feasibility of using a conical design. The advantages of cone filters should also include their small material capacity, the possibility of modular manufacturing for placement at pumping stations, different productivity.

Currently, enough experience has been gained in the design and constructions of mechanical water treatment devices of various types, but the experience of their effective operation is clearly not enough. Keywords: cone filter, flushing flute, screw flow formers, waste removal, ensuring flute rotation.

Герасимов Г. Г., к.т.н., доцент, Герасимов Е. Г., к.т.н. доцент, Иванов С. Ю., инженер (Национальный университет водного хозяйства и природопользования, г. Ровно)

\section{РАСЧЕТ КОНУСНОГО ФИЛЬТРА ДЛЯ ПРЕДВАРИТЕЛЬНОЙ ОЧИСТКИ ВОДЫ}

В статье рассмотрена конструкция конусного фильтра для предварительной механической очистки воды, который располагается внутри напорного трубопровода насосной станции. Выполнен расчет процессов внутренней и внешней промывки сетчатого полотна фильтра и обеспечения допустимой скорости вращения промывной флейты В результате расчетов определены основные геометрические и гидравлические параметры устройства. Ключевые слова: конусный сетчатый фильтр, промывочная флейта, образователи винтового потока, отведение мусора, обеспечения вращения флейты. 